\title{
Value of serum C-reactive protein measurement in the management of bone marrow transplant recipients. Part I: early transplant period
}

\author{
SA WALKER, TR ROGERS, ${ }^{*}$ PAMELA G RICHES, S WHITE, ${ }^{*}$ JR HOBBS \\ From the Protein Reference Unit and ${ }^{*}$ Department of Medical Microbiology, Westminster Hospital and \\ Medical School, London SW1P 2AR
}

SUMMARY Serum C-reactive protein concentrations were measured serially during the early transplant period in 68 bone marrow recipients transplanted for leukaemia (34), chronic granulocytic leukaemia (2), severe aplastic anaemia (6), and various inborn errors of metabolism (26). There were 116 clearly documented episodes of infection or acute graft versus host disease or both. Serum C-reactive protein concentrations in patients with viral (11) or fungal infection (6) were normal or only slightly raised. In 32 patients with isolated acute graft versus host disease, only three $(10 \%)$ showed serum C-reactive protein concentrations above $40 \mathrm{mg} / \mathrm{l}$. Values greater than $40 \mathrm{mg} / 1$ were strongly suggestive of bacterial infections and values above $100 \mathrm{mg} / \mathrm{l}$ were seen only in patients (43) with bacterial infections with or without acute graft versus host disease. These findings suggest that serum $\mathrm{C}$-reactive protein concentrations are valuable both for diagnosis and monitoring of such infections.

Infection and graft versus host disease are still the two major causes of morbidity and mortality during bone marrow transplantation, and they represent the most important barriers to immediate and long term survival. ${ }^{2}$ Acute graft versus host disease may be initiated or exacerbated by infection, ${ }^{3}$ and studies in animals ${ }^{4}$ and $\operatorname{man}^{56}$ have shown that the recipient's microbial environment may significantly modify the incidence and course of the disease. Acute graft versus host disease and its treatment with immunosuppressive drugs increases the incidence of infection, ${ }^{7}$ while the empirical use of broad spectrum antibiotics may increase the risk from invasive fungal infections. ${ }^{8}$ There would therefore be obvious value for any laboratory investigation that could be used in the differential diagnosis and monitoring of these complications, which are often difficult to distinguish clinically and may occur simultaneously.

Infections, particularly bacterial, are associated with an acute phase response, during which the concentrations of many serum proteins are altered. ${ }^{9}$ The nature of the acute phase response in acute graft versus host disease has not been fully investigated.

$\mathrm{C}$-reactive protein (CRP) is one of the most sen-

Accepted for publication 29 May 1984 sitive of the acute phase proteins. It is present in normal serum in trace amounts, and its concentration rises within 8-12 h of an inflammatory stimulus; values can increase 1000 -fold. With recovery from tissue injury or infection the serum CRP concentration falls rapidly. The biology of CRP has recently been reviewed. ${ }^{10}$ CRP has been used in the detection of bacterial infections in patients with leukaemia, ${ }^{11}$ neonates, ${ }^{12} 13$ and in patients with systemic lupus erythematosus ${ }^{14}$; for monitoring disease activity in inflammatory disease ${ }^{15-17}$; for monitoring postoperative complications ${ }^{18}$; and for assessing response to antibiotic treatment. ${ }^{19}$ The lack of response of CRP in most viral infections has led to its use in the differential diagnosis of viral and bacterial infections. ${ }^{20-22}$

We have analysed the serum CRP concentrations found in bone marrow transplant recipients in relation to documented infection and acute graft versus host disease in the early transplant period (less than 3 months after transplant).

\section{Patients and methods}

Sixty eight bone marrow transplant recipients studied longitudinally from admission until dis- 


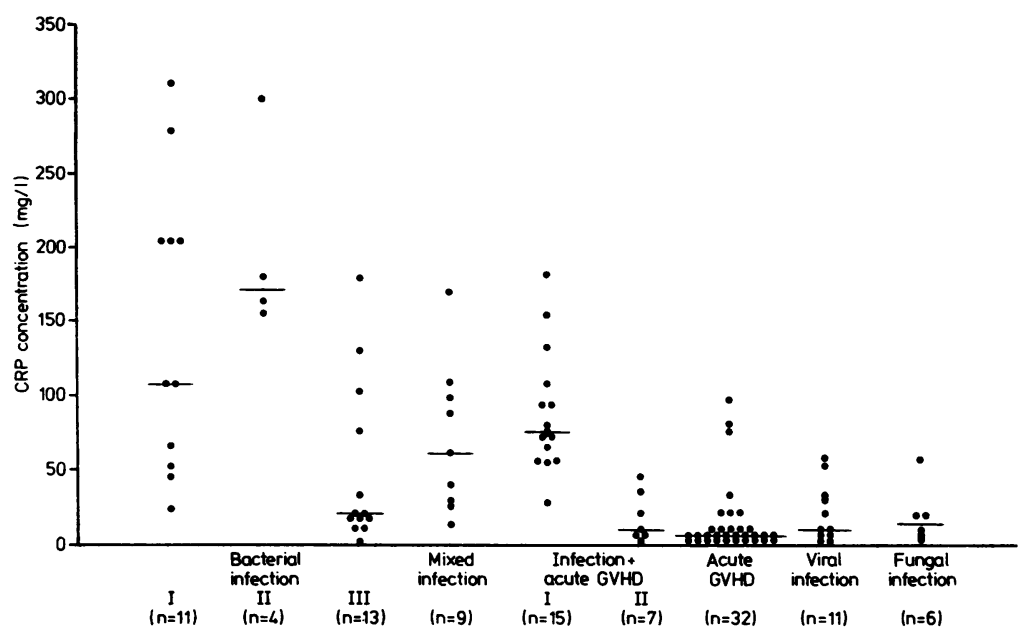

Maximum serum $C$-reactive protein (CRP) concentrations in bone marrow transplant recipients less than three months after transplant. Each point represents the peak serum CRP concentration during an episode of infection or acute graft versus host disease or both.

Bacterial infection: $I$ = microbiologically documented septicaemia; II = clinically documented infection; $I I I=$ microbiologically documented localised infection.

Infection with acute graft versus host disease: $I=$ bacterial: $I I=$ non-bacterial.

Horizontal bar indicates median peak serum CRP concentration for each group.

charge (up to 3 months after transplant) or death had a total of 116 clearly documented episodes of infection or acute graft versus host disease or both. They had been transplanted for acute leukaemia (34), chronic granulocytic leukaemia (2), severe aplastic anaemia (6), and various inborn errors of metabolism (26).

Serum CRP concentrations were measured by rate nephelometry on a Beckman ICS analyser using Beckman reagent kits (Beckman Instruments Inc, Fullerton California 92634, USA) on samples taken regularly from inpatients. The limit of sensitivity was $6 \mathrm{mg} / \mathrm{l}$, and $10 \mathrm{mg} / \mathrm{l}$ was taken as the upper limit of normal. ${ }^{23}$ The coefficient of variation in replicate assays was $6 \%$.

The diagnosis of most bacterial and fungal infections was confirmed by positive culture and supported by a response to appropriate treatment. The diagnosis of viral infections was by electron microscopy, virus isolation, or significantly rising viral antibody titres. In the few patients in whom a causative agent was not identified there was strong clinical evidence of infection or response to treatment or both.

The diagnosis of acute graft versus host disease was usually confirmed by positive biopsy findings in patients developing typical clinical manifestations. ${ }^{24}$

Infection prophylaxis included intestinal decon- tamination, skin and mucosal disinfection, and the provision of sterile or clean cooked food as described previously. ${ }^{25}$ Patients were nursed in cubicles, with reverse barrier nursing maintained until the peripheral neutrophil count exceeded $0.5 \times$ $10^{9} / 1$. Episodes of fever $\left(38^{\circ} \mathrm{C}\right.$ for $2 \mathrm{~h}$ or longer) were treated empirically with azlocillin or piperacillin and gentamicin; when this treatment failed, in the absence of acute graft versus host disease, intravenous amphotericin or antiviral treatment was considered.

Graft versus host disease prophylaxis in adult patients consisted of oral cyclosporin $A$ at a dosage of $12.5 \mathrm{mg} / \mathrm{kg}$ twice daily from four days before until about 120 days after transplant. ${ }^{26}$ Intravenous cyclosporin A was given only when oral absorption was inadequate. Paediatric patients were given oral and intravenous cyclosporin $\mathrm{A}$, with dosage adjusted to maintain adequate plasma concentrations of the drug. When acute graft versus host disease developed, infusions of methyl prednisolone $(1 \mathrm{~g} /$ $\mathrm{m}^{2}$ ) were given 6,8 , or 12 hourly for short pulses followed by rapid stepwise reduction. ${ }^{27}$

The highest serum CRP concentrations reached in patients during episodes of infection or acute graft versus host disease or both were compared. The significance of differences between the patient groups was assessed by the Mann-Whitney test. ${ }^{28}$ 


\section{Results}

The sites and causative agents (where known) of infections occurring in the absence of acute graft versus host disease are shown in Tables 1 to 6 and those occurring in the presence of the disease are shown in Table 7 (see appendix after part II). The maximum CRP concentration during each episode of infection or acute graft versus host disease or both is shown in the Figure, with the medians for patient groups.

In eight bone marrow transplant recipients, five of whom had acute graft versus host disease, streptococcal septicaemia was diagnosed, but, surprisingly, serum CRP concentrations were not increased (median serum CRP $14 \mathrm{mg} / \mathrm{l}$; range $<6-39 \mathrm{mg} / \mathrm{l}$ ). These patients have been excluded from the figure. Serum CRP concentrations were raised in streptococcal septicaemias in seven non-bone marrow transplant recipients, (median serum CRP $152 \mathrm{mg} / \mathrm{l}$; range $63-233 \mathrm{mg} / \mathrm{l}$ ) and in a small number of bone marrow transplant recipients presenting with streptococcal septicaemias later than three months after transplant. ${ }^{31}$ With the exception of streptococcal septicaemias, serum CRP concentrations were significantly higher in bone marrow transplant recipients with major bacterial infections, with or without acute graft versus host disease, than in those with viral infections $(p<0.0001)$, fungal infections $(p<0.001)$, or acute graft versus host disease without bacterial infection ( $p<0 \cdot 0001)$. There was no significant difference between serum CRP concentrations in patients with viral or fungal infections and those with acute graft versus host disease without infection.

In patients with bacterial infections and raised serum CRP concentrations, a favourable clinical response to antibiotic treatment was accompanied by decreasing serum CRP values, with an apparent half life of $24 \mathrm{~h}$. Patients who did not respond had persistently raised serum CRP concentrations (data not shown).

\section{Discussion}

This study has indicated that acute graft versus host disease is not accompanied by significant increases in serum concentrations of the acute phase reactant CRP. With the exception of three patients, the maximum concentrations of serum CRP in acute graft versus host disease were less than $40 \mathrm{mg} / \mathrm{l}$, and values above this were strongly suggestive of major bacterial infection. Furthermore, values above $100 \mathrm{mg} / \mathrm{l}$ were seen only in bacterial infections. Four febrile patients had markedly raised serum CRP concentrations, with strong clinical evidence of infection, and they responded to treatment with antibiotics. Blood cultures, however, were consistently negative. Since most blood cultures are taken to obtain laboratory confirmation of suspected clinical septicaemia and not for the reassurance of a negative result, ${ }^{29}$ increased serum CRP concentrations are a useful laboratory indicator of major bacterial infection when blood cultures are negative. The three patients with acute graft versus host disease and serum CRP concentrations above $40 \mathrm{mg} / 1$ were febrile and were given antibiotics, but they showed a better clinical response to high dosage steroids. Occult bacterial infection, however, may have been present.

In a recent publication ${ }^{30} \mathrm{CRP}$ was found to be increased in acute graft versus host disease whether or not this was complicated by infection; however, the numbers studied were small. In the present series we documented a large number of episodes of acute graft versus host disease without infection, and the inevitable inclusion of some occult bacterial infections would be expected to introduce less bias into the data.

The absence of a CRP response in streptococcal infections during the early transplant period may have reflected low grade bacteraemias complicating Hickman line infections.

Serum CRP concentrations in bone marrow transplant recipients with viral infections were normal or slightly raised as expected, and this was also the pattern seen in the small group of patients with fungal infections. In this study, however, viral and fungal infections occurred less often than bacterial infections.

This study has shown that serial measurement of serum CRP concentrations is valuable in the management of bone marrow transplant recipients with suspected or confirmed bacterial infection. Raised serum CRP concentrations fell rapidly in response to appropriate antibiotics, while in patients in whom raised serum CRP values persisted a change of antibiotics might have been indicated.

In conclusion, a raised serum CRP concentration is a sensitive marker of bacterial infection in bone marrow transplant recipients even in the presence of acute graft versus host disease, which alone gave no appreciable increase. CRP becomes a valuable laboratory parameter to support a diagnosis of bacterial infection when there is strong clinical evidence but blood cultures are negative. The application of rate nephelometry to the measurement of serum CRP allows determination of concentrations within $30 \mathrm{~min}$ of the sample reaching the laboratory. Therefore, in suspected bacterial infections serum CRP concentrations can be monitored to assess response to empirical antibiotic treatment until the 
therapy can be rationalised by identification of the causative agent and its antibiotic sensitivities. It is also probably desirable that serum CRP concentrations should fall to within the normal range before antibiotic treatment is stopped.

\section{References}

' Watson JG. Problems of infection after bone marrow transplantation. J Clin Pathol 1983;36:683-92.

${ }^{2}$ Sullivan KM, Parkman R. The pathophysiology of treatment of GVHD. Clin Haematol 1983;12:775-89.

${ }^{3}$ Pollard M, Chang CF, Srivastava KK. The role of microflora in development of GVHD. Transplant Proc 1976;4:533-6.

${ }^{4}$ Jones JM, Wilson R, Bealmear PM. Mortality and gross pathology of secondary disease in germ-free mouse radiation chimaeras. Radiation Res 1971;45:577-88.

${ }^{5}$ Storb R, Prentice RL, Buckner CD, et al. GVHD and survival in patients with aplastic anaemia treated by marrow grafts from HLA-identical siblings. Beneficial effects of a protective environment. $N$ Engl J Med 1983;308:302-7.

- Vossen JM, Heidt PJ, Guiot HFL, et al. Prevention of acute GVHD in clinical bone marrow transplantation: complete versus selective intestinal decontamination. In: Sasaki S, ed. Recent advances in germ-free research Tokyo: Tokai University Press, 1981:573-7.

' Dowling JN, Wu BC, Armstrong JA, Ho M. Enhancement of murine cytomegalovirus infection during graft-versus-host reaction.J Infect Dis $1977 ; 135: 990-4$.

${ }^{8}$ Rose HD, Varkey B. Deep mycotic infection in the hospitalised adult: a study of 123 patients. Medicine 1975;54:499-507.

' Kushner I. The phenomenon of the acute-phase response. Ann N $Y$ Acad Sci 1982;389:39-48.

${ }^{10}$ Gewurz H, Mold C, Siegel J, Fiedel B. C-reactive protein and the acute-phase response. Adv Intern Med 1982;27:345-71.

" Rose PE, Johnson SA, Meakin M, Mackie PH, Stuart J. Serial study of $C$-reactive protein during infection in leukaemia. $J$ Clin Pathol 1981;34:263-6.

12 Sabel KG, Wadsworth Ch. C-reactive protein in early diagnosis of neonatal septicaemia. Acta Paediatr Scand 1979;68:82531 .

${ }^{13}$ Alt R, Irazuzta J, Erny P, et al. C-reactive protein measurement: a reliable method of diagnosing and monitoring the infected newborn for the assessment of a mezlocillin therapeutic trial. $J$ Antimicrob Chemother 1983;11:51-5.

${ }^{14}$ Becker GJ, Walburger M, Hughes GRV, Pepys MB. Value of serum C-reactive protein measurement in the investigation of fever in systemic lupus erythematosus. Ann Rheum Dis 1980;39:50-2.

is Pepys MB, Druguet M, Klass HJ, Dash AC, Mirjah DD, Petrie A. Immunological studies in inflammatory bowel disease. In: Knight J, Porter R, eds. Immunology of the gut. Ciba Foundation Symposium. Amsterdam: Excerpta Medica, 1977; 46:283-304.
${ }^{16}$ Buckell NA, Lennard-Jones JE, Hernandez MA, Kohn J, Riches PG, Wadsworth J. Measurement of serum proteins during attacks of ulcerative colitis as a guide to patient management Gut 1979;20:22-7.

${ }^{17}$ Amos RS, Constable TJ, Crockson RA, Crockson AP, McConkey B. Rheumatoid arthritis: relation of serum C-reactive protein and erythrocyte sedimentation rates to radiographic changes. $\mathrm{Br}$ Med J 1977;i:95-7.

${ }^{18}$ Fischer CL, Gill C, Forrester MG, Nakamura R. Quantitation of "acute-phase proteins" postoperatively. Value in detection and monitoring of complications. Am J Clin Pathol 1976;66:840-6.

${ }^{19}$ Schofield KP, Voulgari F, Gozzard DI, Leyland MJ, Beeching NJ, Stuart J. C-reactive protein concentration as a guide to antibiotic therapy in acute leukaemia. J Clin Pathol 1982;35:866-9.

${ }^{20}$ McCarthy PL, Frank AL, Ablow RC, Masters SJ, Dolan TF Jr. Value of the $\mathrm{C}$-reactive protein test in the differentiation of bacterial and viral pneumonia. J Pediatr 1978;92:454-6.

${ }^{21}$ Peltola $\mathbf{H}$. C-reactive protein in rapid differentiation of acute epiglottitis from spasmodic croup and acute laryngotracheitis: a preliminary report. J Pediatr 1983;102:713-5.

${ }^{22}$ Clarke D, Cost K. Use of serum C-reactive protein in differentiating septic from aseptic meningitis in children. $J$ Pediatr 1983; 102:718-20.

${ }^{23}$ Shine B, de Beer FC, Pepys MB. Solid-phase radioimmunoassays for human C-reactive protein. Clin Chim Acta 1981;117:1323.

${ }^{24}$ James WD, Odom RB. Graft-versus-host disease. Arch Dermatol 1983;119:683-9.

${ }^{25}$ Rogers TR. Infection complicating bone marrow transplantation. What are the risks and can they be reduced? J Hosp Infect 1982;3:105-9.

${ }^{26}$ Barrett AJ, Kendra JR, Lucas CE, et al. Cyclosporin A as prophylaxis against graft-versus-host disease in 36 patients. $\mathrm{Br}$ Med J 1982; 285: 162-7.

${ }^{27}$ Kendra JR, Barrett AJ, Lucas C, et al. Response of GVHD to high doses of methyl prednisolone. Clin Lab Haematol 1981;3:19-26.

${ }^{28}$ Siegel S. Non-parametric statistics for the behavioural sciences. New York: McGraw-Hill, 1956.

${ }^{29}$ Gould JC, Duerdon BI, eds. Blood culture-current state and future prospects. J Clin Pathol 1983;36:963-77.

${ }^{30}$ Rowe IF, Worsley AM, Donnelly P, et al. Measurement of serum C-reactive protein concentration after bone marrow transplantation for leukaemia. J Clin Pathol 1984;37:263-6.

${ }^{31}$ Walker SA, Riches PG, Rogers TR, White S, Hobbs JR. Value of serum $\mathrm{C}$-reactive protein measurement in the management of bone marrow transplant recipients. Part II: Late posttransplant period. J Clin Pathol 1984;37:1022-6.

Requests for reprints to: Miss SA Walker, Protein Reference Unit, Department of Chemical Pathology, Westminster Hospital, 17, Page Street, London, SW1P 2AR, England. 